\title{
Assessment of hepatitis B immunization programme among school students in Qatar
}

Hamad Al-Romaihi, ${ }_{1}$ Hana Al-Masri, ${ }^{1}$ Sherine Shawky, ${ }^{2}$ Mohammed Al Thani, ${ }^{1}$ Salah Al Awaidy, ${ }^{3}$ Mohamed Ahmed Janahi, ${ }^{4}$ Moutaz Derbala, ${ }^{4}$ Khalid Al-Ansari ${ }^{4}$ and Robert Allison ${ }^{5}$

${ }^{1}$ Ministry of Public Health, Doha, Qatar (Correspondence to: Hana K. Al-Masri: halmasri@moph.gov.qa). ${ }^{2}$ Social Research Center, American University in Cairo, Cairo, Egypt. ${ }^{3}$ Ministry of Health, Muscat, Oman. ${ }^{4}$ Hamad Medical Corporation, Doha, Qatar. ${ }^{5}$ Clinical Center, National Institutes of Health, Bethesda, Maryland, United States of America.

\begin{abstract}
Background: In 2010, Qatar adopted the target of reducing hepatitis B prevalence to $<1 \%$ in children by 2015 . The World Health Organization Region for the Eastern Mediterranean is identified with intermediate hepatitis B virus (HBV) endemicity, ranging from $2 \%$ to $7 \%$. It is estimated that 4.3 million individuals are living with HBV infection in the Region.

Aims: This study was conducted to assess hepatitis B seroprevalence in children, hepatitis B vaccination coverage, potential exposure to risk factors, and knowledge among parents/guardians about hepatitis B infection.

Methods: We carried out this cross-sectional study in Qatar during the academic year 2015/16. Multistage cluster sampling was used to select a nationally representative sample of 2735 grade 1 school students aged $\geq 5$ years. Blood was collected by finger prick and tested using the point-of-care test/rapid test. A self-administered, precoded questionnaire was used to assess parent/guardian knowledge about HBV and collect information on the child's HBV vaccination coverage.

Results: All blood samples were HBsAg negative. Qataris had a vaccination card and were totally vaccinated but $17.7 \%$ of non-Qataris did not hold a vaccination card and most parents/guardians were not aware of the vaccination status of their children. Children were exposed to various hepatitis B risk practices. Knowledge about hepatitis B among parents/ guardians was low.
\end{abstract}

Conclusions: Qatar has averted the hepatitis B threat and maintained high vaccination coverage for children.

Keywords: Qatar, hepatitis B, seroprevalence, children, vaccination

Citation: Al-Romaihi H; Al-Masri H; Shawky S; Al Thani M; Al Awaidy S; Janahi MA; et al. Assessment of hepatitis B immunization programme among school students in Qatar. East Mediterr Health J. 2018;24(8):736-744. https://doi.org/10.26719/2018.24.8.736

Received: 29/03/17; accepted: 19/07/17

Copyright (C) World Health Organization (WHO) 2018. Some rights reserved. This work is available under the CC BY-NC-SA 3.o IGO license (https:// creativecommons.org/licenses/by-nc-sa/3.o/igo).

\section{Introduction}

The hepatitis B virus (HBV) infection takes a heavy toll on lives worldwide. In 2014, the World Health Organization (WHO) estimated that $30 \%$ of the world's population, around 2 billion people, have been infected with HBV and around 360 million have developed chronic liver disease $(1,2)$. Furthermore, HBV has been identified as the cause of up to $80 \%$ of all cases of hepatocellular carcinoma worldwide (3-5). Although HBV-related acute hepatitis may be asymptomatic and may resolve spontaneously, it may also lead to chronic lifelong infection. The main danger of $\mathrm{HBV}$ is in acquiring the infection early in life as progress of the condition towards severe pathological consequences, e.g. liver cirrhosis, liver failure and hepatocellular carcinoma, in adulthood may reach up to $90 \%$ of infected cases (2,6-10). Additionally, mother-to-child transmission results in chronic infection later in life in $90 \%$ of infants infected during the perinatal period and in $80-90 \%$ of infants infected in the first year of life. The risk of chronic $\mathrm{HBV}$ infection declines with age, reaching $30-50 \%$ for children infected between 1 and 4 years of age and only 2-5\% for adolescents and adults (6).

The WHO Eastern Mediterranean Region, which includes Qatar, is identified with intermediate HBV endemicity ranging from 2 to $7 \%$. It is estimated that 4.3 million persons are living with HBV infection in the countries of the Region (11,12). Numerous studies have documented HBV infection as an important cause of liver cirrhosis and hepatocellular carcinoma in the countries of the Region (13-19). In addition to the burden on people's lives, HBV infection drains the resources of the health system because of the cost of treatment for liver cirrhosis and hepatocellular carcinoma.

The limited number of studies on HBV infection in Qatar confirm that the country has not been free of the virus. A study in 1985 showed that $23 \%$ of adult patients with acute viral hepatitis admitted to Hamad General Hospital had HBV infection (20). During 2000-2005, the pathology reports at Qatar Principal Reference Laboratory indicated hepatitis B incidence was $2.5 \%$ among liver disease patients (21). In addition, the incidence of hepatitis B was reported in 2002-2006 as $4.7 \%$ of screened and diagnosed viral hepatitis patients in Hamad General Hospital (22). A study in 2010 reported HBV prevalence of $2.2 \%$ and lack of HBV immunity of $53.3 \%$ among professional male athletes who attended the Qatar Orthopaedic and Sports Medicine Hospital in Doha (23). As reported in these studies, HBV infection was more 
prevalent among non-Qataris than Qataris and among males than females.

The HBV vaccine has been part of the routine infant immunization programme in Qatar since August 1989, when a 3-dose schedule of monovalent vaccine was introduced. In 2000, a birth dose was added, aimed at preventing $70-95 \%$ of $\mathrm{HBV}$ infections. Thereafter in July 2003, a new 4-dose vaccine was introduced in the Expanded Programme on Immunization schedule to accommodate the use of a pentavalent vaccine (DTwPHepB-Hib) and hexavalent vaccine (DtaP, Hep B, Hib and IPV) in addition to the monovalent vaccine at birth. Hepatitis B vaccination coverage has attained maturity over the past 5 years at $93-99 \%$ of all infants.

In 2010, Qatar adopted the WHO target of reducing HBV prevalence among children below 5years of age to $<1 \%$ by 2015 . Furthermore, Qatar aims to establish a certification procedure to document national achievement in hepatitis B control. The certification will be based on hepatitis B surface antigen (HBsAg) prevalence among children of at least 5 years of age who were born after the start of the nationwide hepatitis B vaccination programme. However, current knowledge on the effectiveness of $\mathrm{HBV}$ vaccine on reducing the disease prevalence notably in children is relatively slim.

Thus, this study was conducted to monitor the impact of the HBV vaccination programme in achieving the national and regional target among children aged at least 5 years who received the total vaccination doses, including the birth dose. In other words, the objectives of the study were to measure the HBV seroprevalence in children who benefited from the National vaccination programme; assess the HBV vaccination coverage for these children and the potential exposure to HBV-related risk factors; and assess parent/guardian knowledge about HBV infection. Thus, the study was conducted to fill the existing gap in knowledge on hepatitis B prevalence and to add depth to the vaccination programme in Qatar. The significance of the study goes beyond its contribution to knowledge and regional discourse on the effectiveness of the HBV vaccination programme to draw the attention of the population to the national effort to protect children in Qatar from the HBV threat.

\section{Methods}

\section{Study design and target population}

As it was hypothesized that the new 4-dose HBV vaccination programme had succeeded in reducing hepatitis B prevalence in children of at least 5 years of age to $<1 \%$ and these children are mostly enrolled in grade 1 , a school-based survey was conducted during the academic year 2015-2016 targeting children and their parents/ guardians.

\section{Sample size}

The sample size was calculated using the Epi-Info Statcalc package for prevalence of $1 \%, \alpha$-level 0.05 and design effect 1.5. For the $95 \%$ confidence level, the sample size was estimated to be 2279 children. As it was expected that up to $20 \%$ of the parents/guardians and/or the children themselves may refuse to participate in the survey, the sample was inflated by $20 \%$, thus a total sample of 2735 children was targeted.

\section{Sampling method}

A multistage cluster sampling technique was used to select a nationally representative sample of grade 1 school students attending public and private schools and their parents/guardians. There were 19195 children enrolled in grade 1 in 200 public and private schools in Qatar. A total of 52 schools were selected at random from the list of schools. As the number of students varied markedly by nationality, type of school and sex, sampling was done proportionately. Sampling frames and measure of size were prepared for each municipality by type of school (independent, private international, private approved by education council and private foreign community) and sex (mixed, boys and girls). A total of 51 primary sampling units from 50 schools were selected by systematic random sampling process proportional to school type and sex. In very few cases, notably when only 1 cluster was needed per school type and sex, a simple random process was used.

In the selected schools, registries were used to provide the list of classes and students in grade 1 . If the number of students within a school exceeded the sample size, classes were selected at random and all students within those classes were enrolled in the study. Parents/guardians of selected students were also invited to participate in the study.

\section{Data collection and analysis}

Data collection was carried out during November 2015February 2016 and was consistent in all schools. There were 2 components to the data. The first was the serologic component which included HBsAg testing of students using the point-of-care test/rapid test. This test was used as it is easy to administer and highly flexible. It requires minimal training, no equipment and can be relied upon for fast, accurate diagnosis in the most basic settings. Detecting HBsAg was conducted using the Alere Determine HBsAg rapid test (Abbott Laboratories, Santa Clara, California). The results were produced within 15 minutes with sensitivity $95.16 \%$ and specificity $99.95 \%$. Blood was collected by finger prick to reduce fears among parents/ guardians and children regarding venepuncture as this may affect the participation rate. Chronic HBV infection was assessed by measuring the proportion of HBsAg-positive by rapid test.

The second data collection tool was a standardized, self administered, precoded parent / guardian questionnaire. This was developed in English, translated into Arabic and adapted in order to ensure that it took into account the specific sociocultural realities of the country. The questionnaire was used to assess parent/guardian knowledge about HBV and collect information on child HBV vaccination coverage and the potential exposure 
of children to HBV-related risk factors. Vaccination coverage data were obtained from the child's vaccination card. Where the child did not hold a vaccination card, the parent/guardian was asked to provide the information. The survey was pilot tested in 1 school on 152 children and the questionnaire was pretested on the parents/ guardians prior to the actual fieldwork. The results of the pilot study were included in the final data analysis.

The vaccination status for hepatitis B vaccination at birth (HepB-birth) was defined as:

- fully vaccinated: HepB-birth administered < $24 \mathrm{~h}$ from birth;

- partial vaccinated: HepB-birth administered $>24 \mathrm{~h}$ to $<72$ h from birth;

- not vaccinated: no full or partial HepB-birth vaccination.

The vaccination status for the 3 hepatitis $B$ doses (HepB-3 dose) was defined as:

- fully vaccinated: HBV first dose (HepB1) at 4 months, second dose (HepB2) at 6 months and third dose (HepB3) at 15 months;

- partially vaccinated: invalid HepB2 and/or HepB3 vaccination;

- not vaccinated: no full or partial HepB-3 dose vaccination.

The vaccination status for HepB total was defined as:

- fully vaccinated: HepB-birth, HepB1, HepB2 and HepB3;

- partial vaccination: partial Hep-birth, HepB1 and/or HepB2 and/or HepB3;

- not vaccinated: no full or partial HepB-birth and HepB-3 dose.
Data entry and analysis were done using the SPSS computer package. The chi-squared test was used to assess significant differences between proportions, and Fisher's exact test was used for $2 \times 2$ tables when the chisquared test was not valid. Independent $t$-test was used to detect significant difference between 2 independent means. The significance level was $P<0.05$.

\section{Ethical considerations}

The study proposal was reviewed and approved by the ethical review board of Hamed Medical Cooperation. All selected children and their parents/guardians were invited to participate in the study. Written informed consent from parents/guardians and assent from children were taken prior to data collection. All data were anonymous and confidential. Children and parents/guardians were told that they could refuse to answer any question and withdraw from the study any time.

\section{Results}

\section{Background characteristics of the study sample}

A total of 2803 grade 1 school students were enrolled in the study, 745 (26.6\%) Qataris and 2058 non-Qataris. Boys accounted for $52.8 \%$ of the sample and ages ranged from 5 to 8 years [mean $=6.2$, standard deviation $(\mathrm{SD})=0.6$ ] Over half of the children (58.7\%) were born in Qatar and $51.7 \%$ were in public schools.

The majority of the non-Qatari children were from The Eastern Mediterranean Region (66.8\%), and South East Asia Region (27.8\%). The rest were from Europe (3.7\%), Africa (1.1\%), the United States of America and Canada (0.3\%) and Western Pacific Region (0.1\%).

Table 1 provides the background characteristics of grade 1 school students in Qatar. The proportion of boys was 55.4\% among Qatari students and 51.8\% among

\begin{tabular}{|c|c|c|c|c|c|c|}
\hline \multirow[t]{2}{*}{ Characteristic } & \multicolumn{2}{|c|}{ Qatari $(n=745)$} & \multicolumn{2}{|c|}{ Non-Qatari $(n=2058)$} & \multicolumn{2}{|c|}{ Total $(n=2803)$} \\
\hline & No. & $\%$ & No. & $\%$ & No. & $\%$ \\
\hline \multicolumn{7}{|l|}{ Sex } \\
\hline Male & 413 & 55.4 & 1067 & 51.8 & 1480 & 52.8 \\
\hline Female & 332 & 44.6 & 991 & 48.2 & 1323 & 47.2 \\
\hline \multicolumn{7}{|l|}{ Age (years) ${ }^{* * *}$} \\
\hline 5 & 46 & 6.2 & 1219 & 10.6 & 265 & 9.5 \\
\hline 6 & 528 & 70.9 & 1342 & 65.2 & 1870 & 66.7 \\
\hline 7 & 166 & 22.3 & 448 & 21.8 & 614 & 21.9 \\
\hline 8 & 5 & 0.7 & 49 & 2.4 & 54 & 1.9 \\
\hline \multicolumn{7}{|l|}{ Place of birth ${ }^{* * *}$} \\
\hline Qatar & 734 & 98.5 & 912 & 44.3 & 1646 & 58.7 \\
\hline Outside Qatar & 11 & 1.5 & 1146 & 55.7 & 1157 & 41.3 \\
\hline \multicolumn{7}{|l|}{ Type of school ${ }^{* * *}$} \\
\hline Public & 579 & 77.7 & 869 & 42.2 & 1448 & 51.7 \\
\hline Private & 166 & 22.3 & 1189 & 57.8 & 1355 & 48.3 \\
\hline
\end{tabular}


the non-Qataris. The difference was not statistically significant. The age range for both Qataris and nonQataris was around 5-8 years, and Qatari students were significantly slightly older than non-Qataris (Qataris: mean $=6.4, \mathrm{SD}=0.9$ years; non-Qataris mean $=6.2, \mathrm{SD}$ $=0.7$ years). Almost all the Qataris (98.5\%) were born in Qatar compared to only $44.3 \%$ of non-Qataris $(P<0.001)$.

\section{Hepatitis B seroprevalence}

As shown in Table 2, 2562 of our students (91.4\% of the study sample) agreed to have the HBsAg testing using the point-of-care test, and 2538 tests (99.1\%) were valid. All blood samples tested negative for HBsAg. These results clearly indicate that none of the tested students had HBV infection.

\section{Hepatitis B vaccination coverage}

All Qatari students and $82.3 \%$ of non-Qataris had a vaccination card (Table 3). All Qatari students in the sample, whether born in Qatar or outside, were fully vaccinated with HepB-birth and HepB-3dose. For the non-Qataris holding a vaccination card, $96.3 \%$ were full vaccinated with HepB-birth, 99.0\% with HepB-3 dose, with a total of $96.2 \%$ fully vaccinated. There were 64 students $(3.8 \%$ of

\begin{tabular}{|c|c|c|c|c|c|c|}
\hline \multirow[t]{2}{*}{ Test status } & \multicolumn{2}{|c|}{ Qatari $(n=745)$} & \multicolumn{2}{|c|}{ Non-Qatari $(n=2058)$} & \multicolumn{2}{|c|}{ Total $(n=2803)$} \\
\hline & No. & $\%$ & No. & $\%$ & No. & $\%$ \\
\hline Hep B negative & 666 & 89.4 & 1872 & 91.0 & 2538 & 90.5 \\
\hline Invalid & 2 & 0.3 & 22 & 1.1 & 24 & 0.9 \\
\hline Sample not taken & 77 & 10.3 & 164 & 8.0 & 241 & 8.6 \\
\hline
\end{tabular}

Table 3 Hepatitis B vaccine status in grade 1 school students in Qatar, 2015-2016

\begin{tabular}{|c|c|c|c|c|c|c|}
\hline \multirow[t]{2}{*}{ Vaccination status } & \multicolumn{2}{|c|}{$\begin{array}{c}\text { Qatari } \\
(n=745)\end{array}$} & \multicolumn{2}{|c|}{$\begin{array}{l}\text { Non-Qatari } \\
(n=2058)\end{array}$} & \multicolumn{2}{|c|}{$\begin{array}{c}\text { Total } \\
(n=2803)\end{array}$} \\
\hline & No. & $\%$ & No. & $\%$ & No. & $\%$ \\
\hline & \multicolumn{6}{|c|}{ Vaccination card holders } \\
\hline & \multicolumn{2}{|c|}{$(n=745)$} & \multicolumn{2}{|c|}{$(n=1694)$} & \multicolumn{2}{|c|}{$(n=2439)$} \\
\hline \multicolumn{7}{|l|}{ HepB-birth } \\
\hline Fully vaccinated & 745 & 100.0 & 1632 & 96.3 & 2377 & 97.5 \\
\hline Partial vaccination & 0 & 0.0 & 4 & 0.2 & 4 & 0.2 \\
\hline Not covered & 0 & 0.0 & 58 & 3.4 & 58 & 2.4 \\
\hline \multicolumn{7}{|l|}{ НерВ-3 dose $\left(\right.$ НерВ1+НерВ2+НерВ3) ${ }^{* *}$} \\
\hline Fully vaccinated & 745 & 100.0 & 1677 & 99.0 & 2422 & 99.3 \\
\hline Partial vaccination & 0 & 0.0 & 17 & 1.0 & 17 & 0.7 \\
\hline \multicolumn{7}{|c|}{ Hep B total (At birth + HepB1+HepB2+HepB3) $)^{* * *}$} \\
\hline Fully vaccinated & 745 & 100.0 & 1630 & 96.2 & 2375 & 97.4 \\
\hline \multirow[t]{3}{*}{ Partial vaccination } & 0 & 0.0 & 64 & 3.8 & 64 & 2.6 \\
\hline & \multicolumn{6}{|c|}{ Non-vaccination card holders } \\
\hline & \multicolumn{2}{|c|}{$(n=0)$} & \multicolumn{2}{|c|}{$(n=364)$} & \multicolumn{2}{|c|}{$(n=364)$} \\
\hline \multicolumn{7}{|l|}{ HepB-birth } \\
\hline Covered & - & - & 105 & 28.8 & 105 & 28.8 \\
\hline Not covered & - & - & 41 & 11.3 & 41 & 11.3 \\
\hline Don't know/no response & & & 218 & 59.9 & 218 & 59.9 \\
\hline НерВ-3 dose (НерВ1+НерВ2+НерВ3) & - & - & & & & \\
\hline Covered & - & - & 45 & 12.4 & 45 & 12.4 \\
\hline Not covered & - & - & 72 & 19.8 & 72 & 19.8 \\
\hline Don't know/no response & - & - & 247 & 67.9 & 247 & 67.9 \\
\hline \multicolumn{7}{|c|}{ Hep B total (At birth + HepB1+HepB2+HepB3) } \\
\hline Covered & - & - & 27 & 7.4 & 27 & 7.4 \\
\hline Not covered & - & - & 21 & 5.8 & 21 & 5.8 \\
\hline Don't know/no response & - & - & 316 & 86.8 & 316 & 86.8 \\
\hline
\end{tabular}

${ }^{*} P<0.01,{ }^{* *} P<0.001$. 
non-Qataris holding a vaccination card) who were partially vaccinated as they were either partially or not vaccinated with HepB-birth and/or HepB-3dose. They were all from India, born in their home country and $74.2 \%$ of them were in private schools.

All of the 364 non-Qatari grade 1 school students who had no vaccination card were born outside Qatar, mainly in countries of the WHO Eastern Mediterranean Region (69.8\% of non-vaccination card holders) and South East Asia (22.5\%). They were from Egypt (33.8\%), Syrian Arab Republic $(15.4 \%)$ and India $(17.3 \%)$, and $70.9 \%$ were private school students. Two-thirds of the parents/guardians did not know whether their children had received HepB-birth and $86.8 \%$ were not able to declare the vaccination status of their children. However, $28.8 \%$ of these children were known to have received HepB-birth, $12.4 \%$ were known to have received HepB-3-dose and 7.4\% were known to be totally vaccinated.

\section{Previous exposure to hepatitis B risk factors}

As with children in this age group, grade 1 school students are liable to falling sick and receiving health care (Table 4). Around a third of the children had had dental treatment, $21.9 \%$ were ever hospitalized, $21.4 \%$ had received injections in hospitals, $13.4 \%$ had a surgical treatment and $4.7 \%$ had received injections at home. The proportion of Qatari children receiving dental care was significantly higher than the non-Qatari children while the proportion of children receiving other medical care procedures was significantly higher in non-Qataris than Qataris (Table 4). Around $10 \%$ of the children had received health care in the form of surgery, dental care and/or blood transfusion outside Qatar with significantly higher proportions among non-Qataris (11.7\%) than Qataris (4.0\%).

Other risk practices are detailed on Table 4. Few children $(0.5 \%)$ had tattoos, and this was the same for Qataris and non-Qataris.

\section{Parent/guardian knowledge about hepatitis B viral infection}

Table 5 shows the knowledge of parents/guardians of grade 1 school students about hepatitis B viral infection. We found that $70.0 \%$ of parents/guardians had heard about HBV infection, $16.8 \%$ knew of a person who had died from the infection but just $17.0 \%$ had received information about HBV infection in the 6 months prior to data collection.

The proportion of parents/guardians who knew that blood was a route of transmission ranged from 49.0$58.2 \%$. The proportion of parents/guardians who knew of the other routes of transmission was low, 31.0\% for sexual transmission, $38.4 \%$ for vertical mother-to-child transmission and $18.9 \%$ for transmission through breastfeeding. In general, non-Qataris had significantly better knowledge about HBV infection than Qataris. However, at least one-third of parents/guardians had a number of misconceptions about HBV, and this was significantly higher among non-Qataris than Qataris.

\section{Discussion}

Since the introduction of the new 4-dose HBV vaccine in the national Expanded Programme on Immunization, great progress has been achieved in Qatar towards the elimination of HBV infection in children. All grade 1 school children tested for HBsAg in our study tested negative. There is very limited information on HBV prevalence in children; the latest available figures document a prevalence of $0.8 \%$ in 5-14-year-old children (21), which is an indication that Qatar was moving towards achieving the regional target of reducing the prevalence of HBV in-

\begin{tabular}{|c|c|c|c|c|c|c|}
\hline \multirow[t]{2}{*}{ Previous exposure to risk factors } & \multicolumn{2}{|c|}{$\begin{array}{c}\text { Qatari } \\
(n=745)\end{array}$} & \multicolumn{2}{|c|}{$\begin{array}{l}\text { Non-Qatari } \\
(n=2058)\end{array}$} & \multicolumn{2}{|c|}{$\begin{array}{c}\text { Total } \\
(n=\mathbf{2 8 0 3})\end{array}$} \\
\hline & No. & $\%$ & No. & $\%$ & No. & $\%$ \\
\hline \multicolumn{7}{|l|}{ Healthcare procedures } \\
\hline Ever had any surgery & 98 & 13.2 & 278 & 13.5 & 376 & 13.4 \\
\hline Ever had transfusion of blood or blood products & 7 & 0.9 & 19 & 0.9 & 26 & 0.9 \\
\hline Ever got injection treatment in hospital ${ }^{* * *}$ & 76 & 10.2 & 524 & 25.5 & 600 & 21.4 \\
\hline Ever got injection treatment at home $e^{* * *}$ & 9 & 1.2 & 123 & 6.0 & 132 & 4.7 \\
\hline Ever been hospitalized & 150 & 20.1 & 464 & 22.5 & 614 & 21.9 \\
\hline Ever had dental treatment* & 277 & 37.2 & 671 & 32.6 & 948 & 33.8 \\
\hline $\begin{array}{l}\text { Had any surgery, blood transfusion, injections or dental care } \\
\text { outside Qatar*** }\end{array}$ & 30 & 4.0 & 240 & 11.7 & 270 & 9.6 \\
\hline \multicolumn{7}{|l|}{ Other procedures } \\
\hline Ever had ears or other body parts pierced ${ }^{* *}$ & 170 & 22.8 & 597 & 29.0 & 767 & 27.4 \\
\hline Ever had tattoo & 4 & 0.5 & 10 & 0.5 & 14 & 0.5 \\
\hline $\begin{array}{l}\text { Ever shared (even sometimes) toothbrush with family } \\
\text { members* }\end{array}$ & 95 & 12.8 & 211 & 10.3 & 306 & 10.9 \\
\hline
\end{tabular}

${ }^{*} \mathrm{P}<0.05,{ }^{* *} \mathrm{P}<0.01,{ }^{\text {***}} \mathrm{P}<0.001$. 


\begin{tabular}{|c|c|c|c|c|c|c|}
\hline \multirow[t]{2}{*}{ Knowledge question } & \multicolumn{2}{|c|}{$\begin{array}{l}\text { Qatari } \\
(\mathrm{n}=745)\end{array}$} & \multicolumn{2}{|c|}{$\begin{array}{l}\text { Non-Qatari } \\
(\mathrm{n}=\mathbf{2 0 5 8})\end{array}$} & \multicolumn{2}{|c|}{$\begin{array}{c}\text { Total } \\
(\mathrm{n}=\mathbf{2 8 0 3})\end{array}$} \\
\hline & No. & $\%$ & No. & $\%$ & No. & $\%$ \\
\hline \multicolumn{7}{|l|}{ General } \\
\hline Ever heard about the illness hepatitis $\mathrm{B}^{* * *}$ & 406 & 54.5 & 1555 & 75.6 & 1961 & 70.0 \\
\hline Know anyone who is infected with hepatitis B or who has died of hepatitis $B^{* * *}$ & 82 & 11.0 & 390 & 19.0 & 472 & 16.8 \\
\hline Heard, seen, or received any information about hepatitis B in the last 6 months* & 101 & 13.6 & 375 & 18.2 & 476 & 17.0 \\
\hline \multicolumn{7}{|l|}{ Blood } \\
\hline $\begin{array}{l}\text { A person can get hepatitis B from contaminated transfusions of blood or blood } \\
\text { products }^{* * *}\end{array}$ & 306 & 41.1 & 1322 & 64.2 & 1628 & 58.1 \\
\hline $\begin{array}{l}\text { A person can get hepatitis B from injections with contaminated syringes in } \\
\text { health-care settings *** }\end{array}$ & 298 & 40.0 & 1334 & 64.8 & 1632 & 58.2 \\
\hline A person can get hepatitis B from contaminated needles used in ear piercing *** & 233 & 31.3 & 1151 & 55.9 & 1384 & 49.4 \\
\hline A person can get hepatitis B from contaminated needles used in tattooing ${ }^{* * *}$ & 259 & 34.8 & 1220 & 59.3 & 1479 & 52.8 \\
\hline $\begin{array}{l}\text { A person can get hepatitis B by getting injections with a needle already used by } \\
\text { someone else } e^{\star \star \star}\end{array}$ & 306 & 41.1 & 1325 & 64.4 & 1631 & 58.2 \\
\hline A person can get hepatitis B by injecting drug*** & 265 & 35.6 & 1109 & 53.9 & 1374 & 49.0 \\
\hline A person can get hepatitis B by sharing razors with an infected person *** & 255 & 34.2 & 1218 & 59.2 & 1473 & 52.6 \\
\hline \multicolumn{7}{|l|}{ Unprotected sex } \\
\hline A person can get hepatitis B from unprotected sex with an infected partner*** & 165 & 22.1 & 704 & 34.2 & 869 & 31.0 \\
\hline \multicolumn{7}{|l|}{ Mother to child } \\
\hline $\begin{array}{l}\text { A pregnant can woman infected with hepatitis B transmit the virus to her } \\
\text { unborn child }\end{array}$ & 219 & 29.4 & 857 & 41.6 & 1076 & 38.4 \\
\hline $\begin{array}{l}\text { A woman with hepatitis B can transmit the virus to her newborn child through } \\
\text { breastfeeding*** }\end{array}$ & 124 & 16.6 & 406 & 19.7 & 530 & 18.9 \\
\hline \multicolumn{7}{|l|}{ Misconceptions } \\
\hline A healthy-looking person can be infected with hepatitis $B^{* * *}$ & 159 & 21.3 & 936 & 45.5 & 1095 & 39.1 \\
\hline A person can get hepatitis B by shaking hands with an infected person & 75 & 10.1 & 169 & 8.2 & 244 & 8.7 \\
\hline A person can get hepatitis B from mosquito or insect bites ${ }^{* * *}$ & 127 & 17.0 & 485 & 23.6 & 612 & 21.8 \\
\hline $\begin{array}{l}\text { A person can get hepatitis B by sharing food or drink with someone who is } \\
\text { infected }\end{array}$ & 138 & 18.5 & 385 & 18.7 & 523 & 18.7 \\
\hline
\end{tabular}

fection to $<1 \%$ by 2015 . Furthermore, there were no HBV cases reported in Qatar during 2013-2015 in the 0-4-yearold children (unpublished data, Ministry of Public Health national statistics, 2016). Thus, our results confirm this progress and demonstrate the success of Qatar in eliminating HBV infection in children who benefited from the new 4-dose vaccine in the national Expanded Programme on Immunization. The reason for this success resides in the HBV control strategy in Qatar. The country offers the 4-dose Expanded Programme on Immunization services free of charge to all citizens. The primary health care centres throughout the country offer free hepatitis B vaccination to all children regardless of nationality. НepBbirth is administered to all children born in hospitals, i.e. almost all births in the country. There is high-quality vaccine management in place to address shortage and ensure availability for all children. The Department of Health Protection and Communicable Diseases in the Ministry of Public Health has a tracking system to count the number of children requiring vaccination and ensure coverage. Our findings provide evidence on the high vaccination coverage in the country which reaches $100 \%$ in Qatari children. Our results have also shown that 82.3\% of non-Qatari children had a vaccination card and almost all were fully vaccinated, giving a total coverage for these children of $96.2 \%$. These results correspond with the data provided by administrative records in 2015 showing HBV vaccination coverage of $95-99 \%$ in the same age group (unpublished data, Ministry of Public Health, 2015). Previous experience in the Region using the 4-dose schedule in the Expanded Programme on Immunization and a similar HBV control strategy (24) has shown a dramatic decrease in chronic HBV seroprevalence in children, as is the case of Qatar.

It is clear that despite the efforts exerted by Qatar public health authorities, there is still a need for further action to maintain the current success in HBV control. Qatar faces several challenges in its fight against HBV infection. Over the past decade Qatar has offered numerous job opportunities to expatriates from all over the globe to 
support its labour force. This strategy has attracted many who found a place to work and live with their families. Our results show that some countries do not have strict enforcement of the vaccination programme: $31.8 \%$ of the non-Qatari children born outside Qatar did not have a vaccination card and the majority of parents/guardians did not know the vaccination status of their children. This makes it difficult for the health system to spot these children and apparently some remain unreached. This is further aggravated by the fact that around $10 \%$ of nonQatari children are more prone to seek health care outside Qatar. This has been demonstrated before for adults, a situation that put them at risk of contracting viral hepatitis (25). It was postulated that non-Qataris prefer to seek health care outside Qatar for several reasons such as limited financial resources, work overload, belief that their home country's healthcare system responds better to their health needs and fear of losing their job.

Health needs and practices in the childhood period cannot be neglected. Children from different countries may have different health needs; different cultural norms and practices may put them at risk of HBV transmission. Our results have shown that Qataris are more in need of dental care while non-Qataris are more in need of medical care. Furthermore, ear piercing, tattooing and sharing tooth brush are practiced by both non-Qataris and Qataris. All these practices need effective control measures to prevent the spread of blood-borne infections, including HBV.

Our study reports that there was a gap in HBV- related knowledge among parents/guardians, with misconceptions prevalent among both Qataris and non-Qataris. Non-Qataris had better HBV knowledge than Qataris, yet they had more misconceptions and showed less appreciation to the role of vaccination in controlling HBV infection. This highlights the need for rigorous awareness campaigns responding to the needs of different traditions and cultures and directed to both Qataris and non-Qataris.

It is apparent from our results that some schools, particularly in the private sector, do not request the child vaccination card upon school entry. It is, therefore, clear that with the poor knowledge base of parents/guardians, these children may remain out of the reach of the health services.

This study had some limitations. As the questionnaires were self-administered, parents/guardians may not have been accurate in responding to some information. Yet, parents/guardians were asked to copy the vaccination status of the children from the vaccination card and for non-vaccination card holders, results were analysed separately to avoid any information bias. Furthermore, the research team had close contact with the parents/ guardians to ensure completeness of information and avoid non-response. Chronic HBV infection was assessed by measuring the proportion of HBsAg-positive seroprevalence by the rapid test to avoid false positive results. We planned to confirm positive results by taking a venous blood sample, however all results were negative.

\section{Acknowledgements}

The authors are indebted to all who contributed to make this research possible, notably Afrah Moosa Ali, Primary Health Care Corporation and Habiba Mubarak Al Kuwari, Primary Health Care Corporation. Special thanks to all physicians of Qatar Ministry of Public Health, especially Dr Mohamed Ahmed Sallam, Dr Aiman Aly Elberdiny, Dr Ahmed M. El-Sayed, Dr Menatalla Ahmed Mahmoud El-Refay, Dr Samina Fatima Hasnain, Dr Rashad Qaid Algumaei, Dr Shazia Nadeem, Head of Surveillance and Outbreaks, and Dr Jalilah Barodi Moksir.

Funding: This research was fully sponsored by Qatar Ministry of Public Health.

Competing interests: None declared.

\section{Évaluation d'un programme de vaccination contre l'hépatite B parmi des élèves au Qatar}

\section{Résumé}

Contexte : En 2010, le Qatar a adopté une cible consistant à réduire la prévalence de l'hépatite Bà moins de $1 \%$ chez l'enfant d'ici 2015. La Région OMS de la Méditerranée orientale a été identifiée comme une région d'endémicité intermédiaire pour le virus de l'hépatite B, avec un taux compris entre 2 et $7 \%$. On estime que 4,3 millions de personnes dans la Région vivent avec une infection par le virus de l'hépatite B.

Objectif : La présente étude a été menée dans le but d'évaluer la séroprévalence de l'hépatite B chez l'enfant, la couverture vaccinale associée, le risque d'exposition aux facteurs de risque, et la connaissance de l'infection par le virus de l'hépatite $B$ parmi les parents/tuteurs.

Méthodes : La présente étude transversale a été réalisée au Qatar pendant l'année scolaire 2015-2016. L'échantillonnage en grappe à plusieurs niveaux a été la technique utilisée pour sélectionner un échantillon national représentatif de 2735 élèves de première année du primaire, âgés de cinq ans ou plus. Un prélèvement de sang a été réalisé par piqûre au doigt et un dépistage a été effectué à l'aide d'un test sur le lieu de soins/test rapide. Un questionnaire auto-administré 
précodé a été utilisé pour évaluer les connaissances des parents/tuteurs en matière d'hépatite $B$ et recueillir des informations sur la couverture vaccinale des enfants contre l'hépatite B.

Résultats : Tous les échantillons sanguins étaient négatifs pour l'antigène de surface du virus de l'hépatite B. Les Qataris possédaient un carnet de vaccination et étaient complètement vaccinés, mais $17,7 \%$ des non-Qataris ne possédaient pas de carnet de vaccination et la plupart des parents/tuteurs ne connaissaient pas le statut vaccinal de leurs enfants. Les enfants étaient exposés à différentes pratiques à risque pour l'hépatite B. Les connaissances des parents/tuteurs sur l'hépatite B étaient faibles.

Conclusion : Le Qatar a su écarter la menace de l'hépatite B et maintenir une couverture vaccinale élevée pour les enfants.

$$
\begin{aligned}
& \text { تقييم برنامج تطعيم طلاب المدارس ضد التهاب الكبد B في قطر } \\
& \text { حمد الرميحي، هناء المصري، شيرين شوقي، محمد آل ثاني، صلاح العويدي، محمد أحمد جناحي، معتز دربالة، خالد الأنصاري، روبرت أليسون }
\end{aligned}
$$

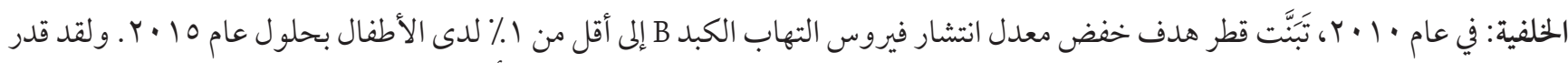

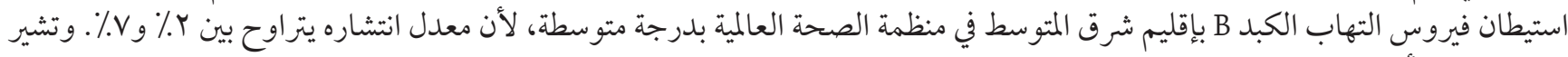

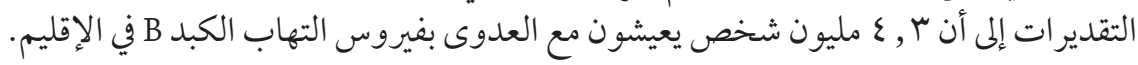

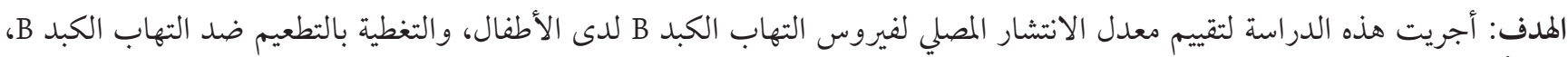

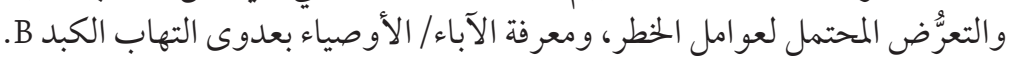

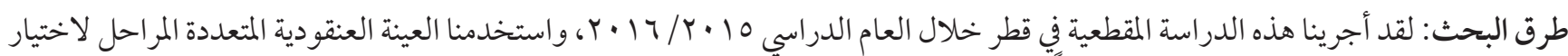

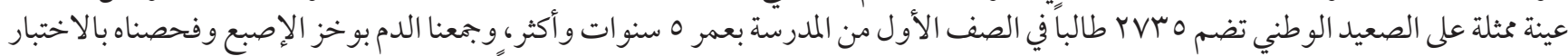

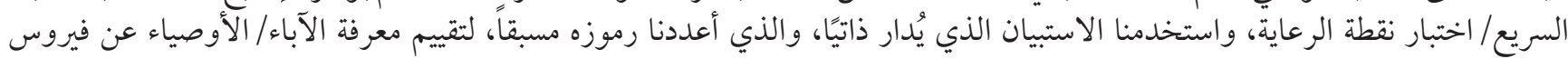

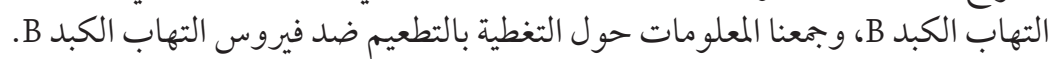

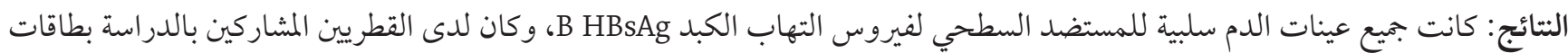

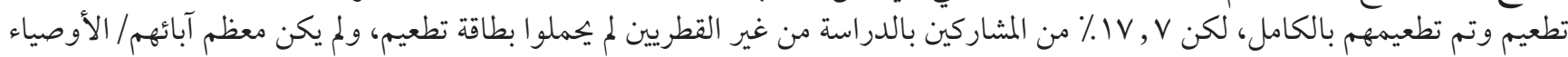

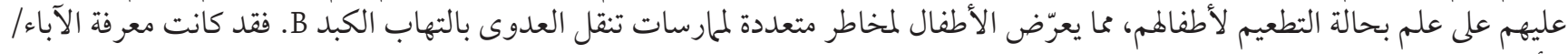
الأوصياء بالتهاب الكبد B منخفضة.

الاستنتاج: لقد تفادت قطر تهديد التهاب الكبد B و مافظت على تغطية عالية لتطعيم الأطفال ضدهد.

\section{References}

1. World Health Organization. Hepatitis B vaccines. Wkly Epidemiol Rec. 2009 Oct;84(40):405-19 (http://www.who.int/wer/2009/ wer8440.pdf). PMID:19817017.

2. Hepatitis B. Fact sheet No. 204, updated. Geneva: World Health Organization; 2014.

3. Ganem D, Schneider RJ. Hepadnaviridae: the viruses and their replication In: Fields BN, Knipe DM, Howley PM, Griffin DE, eds. Fields virology, 4th ed. Philadelphia. Lippincott Williams \& Wilkins; 2001: 2923-69.

4. Hepatitis B. Geneva: World Health Organization, Department of Communicable Disease Surveillance and Response; 2002 (http:// www.who.int/csr/disease/hepatitis/HepatitisB_whocdscsrlyo2002_2.pdf, accessed 20 December 2014).

5. Introduction of hepatitis B vaccine into childhood immunization services. Geneva: World Health Organization; 2001 (http:// www.wpro.who.int/hepatitis/whovbo131.pdf?ua=1, accessed 18 March 2018).

6. Documenting the impact of hepatitis B immunization: best practices for conducting a serosurvey. Geneva: World Health Organization; 2011 (WHO/IVB/11.08; http://whqlibdoc.who.int/hq/2011/WHO_IVB_11.08_eng.pdf, accessed 16 March 2018).

7. WHO Regional Committee for the Eastern Mediterranean resolution EM/RC56/R.5 on the growing threats of hepatitis B and C in the Eastern Mediterranean Region: a call for action; October 2009. Fez, Morocco: WHO Regional Office for the Eastern Mediterranean; 2009 (http://www.who.int/immunization/sage/EMRO_RC56_final_report_short.pdf, accessed 16 March 2018).

8. Hollinger FB, Liang TJ. Hepatitis B virus. In: Knipe DM, Howley PM, Griffin DE, eds. Fields virology, 4th ed. Philadelphia: Lippincott Williams \& Wilkins; 2001:2971-3036.

9. Robinson WS. Hepatitis B viruses. General features (human). In: Webster RG, Granoff A, eds. Encyclopedia of virology. London: Academic Press Ltd; 1994:554-69.

10. Robinson WS. Hepatitis B virus and hepatitis D virus. In: Mandell GL, Bennett JE, Dolin R, eds: Principles and practice of infectious diseases, 4th ed. New York, Churchill Livingstone, 1995:1406-39. 
11. The growing threats of hepatitis B and C in the Eastern Mediterranean Region: a call for action (Technical paper presented at the fifty-sixth session of the WHO Regional Committee for the Eastern Mediterranean, 2009 (EM/RC56/3; http://applications.emro. who.int/docs/EM_RC56_3_en.pdf, accessed 16 March 2018).

12. Qureshi H. Hepatitis B infection in the Eastern Mediterranean Region: challenges and the way forward. East Mediterr Health J. 2013 Jul;19(7):585-6. PMID:24975300

13. Perz JF, Armstrong GL, Farrington LA, Hutin YJF, Bell BP. The contributions of hepatitis B virus and hepatitis C virus infections to cirrhosis and primary liver cancer worldwide. J Hepatol. 2006 Oct;45(4):529-38. https://doi.org/10.1016/j.jhep.2006.05.013 PMID:16879891

14. Triki H. [Epidemiology of hepatitis B virus, hepatitis $C$ virus and Delta virus in the general population and in liver cirrhosis in Tunisia]. Arch Inst Pasteur Tunis. 1994 Jul-Oct;71(3-4):403-6. PMID:8801835 (in French)

15. Darwish MA, Amer AF, El-Moeity AA, Darwish NM. Association of hepatitis C virus with liver cirrhosis and hepatocellular carcinoma compared with hepatitis B virus in Egyptian patients. J Egypt Public Health Assoc. 1997;72(5-6):569-89. PMID:17214153

16. Bukhtiari N, Hussain T, Iqbal M, Malik AM, Qureshi AH, Hussain A. Hepatitis B and C single and co-infection in chronic liver disease and their effect on the disease pattern. J Pak Med Assoc. 2003 Apr;53(4):136-40. PMID:12776896

17. Hajiani E, Masjedizadeh R, Hashemi J, Azmi M, Rajabi T. Risk factors for hepatocellular carcinoma in Southern Iran. Saudi Med J. 2005 Jun;26(6):974-7. PMID:15983686

18. Ayoola EA, Gadour MO. Hepatocellular carcinoma in Saudi Arabia: role of hepatitis B and C infection. J Gastroenterol Hepatol. 2004 Jun;19(6):665-9. https://doi.org/10.1111/j.1440-1746.2003.03334.x PMID:15151622

19. El-Zayadi AR, Badran HM, Barakat EM, Attia Mel-D, Shawky S, Mohamed MK, et al. Hepatocellular carcinoma in Egypt: a single center study over a decade. World J Gastroenterol. 2005 Sep 7;11(33):5193-8. PMID:16127751

20. Glynn MJ, Rashid A, Antao AJO, Coleman JC, Howard CR, Zuckerman AJ, et al. Imported epidemic non-A, non-B hepatitis in Qatar. J Med Virol. 1985 Dec;17(4):371-5. https://doi.org/10.1002/jmv.1890170409 PMID:3935751

21. Rikabi A, Bener A, Al-Marri A, Al-Thani S. Hepatitis B and C viral infections in chronic liver disease: a population based study in Qatar. East Mediterr Health J. 2009 Jul-Aug;15(4):778-84. PMID:20187528

22. Bener A, Al-Kaabi S, Derbala M, Al-Marri A, Rikabi A. The epidemiology of viral hepatitis in Qatar. Saudi J Kidney Dis Transpl. 2009;20(2):300-6. PMID:19237827

23. Mamilton BH, Paoloni JA, Chalabi H. Epidemiology of hepatitis B among professional male athletes in Qatar. Saudi Med J. 2010;31(6):678-683. PMID:20563368

24. Al Awaidy ST, Bawikar SP, Al Busaidy SS, Al Mahrouqi S, Al Baqlani S, Al Obaidani I, et al. Progress toward elimination of hepatitis B virus transmission in Oman: impact of hepatitis B vaccination. Am J Trop Med Hyg. 2013 Oct;89(4):811-5. doi:10.4269/ajtmh.13-0333 PMID:23958910

25. Al Romaihi HE, Farag E, Al-Hajri MA, Al Thani M, Al-Masri H, Ismail A, et al. Viral hepatitis C serological and behavioral survey among single male laborers in Qatar, J Emergency Med, Trauma \& Acute Care, Special Issue of International Conference in Emergency Medicine and Public Health - Qatar, 99. 2016 https://doi.org/10.5339/jemtac.2016.icepq.99 